\title{
Power and the Working Life
}

\author{
By Carter Goodrich \\ Department of Economics, University of Michigan
}

$\mathrm{O}^{\mathrm{F}}$ F all the social changes that the innocent revolutionists of what we call the industrial revolution have brought down upon an unsuspecting society, none are sharper than those in the kind of life men lead during their working hours. It is the building of the modern factory in the place, say, of the "neighborly "ten-footer'shop" in which the "fisherman-farmer-shoemakers" of the North Shore used to ply their "sociable handicraft," that is the most obvious mark of the movement. And few of its results are affecting the quality of modern civilization more intimately than those symbolized on the one hand by the sight of the craneman touching a few levers to do the tugging and hauling that has strained the backs of the pyramid-builders and their successors throughout the ages, and on the other hand by the "fascinating and horrible spectacle" of the jobs along the famous assembly line at Highland Park out of which the last residue of workmanlike interest has been relentlessly squeezed.

Yet these effects, like so many of the most important results of the revolution in technique, have been for the most part quite unintended. No one planned the tremendous increase in population or the swelling of cities; there has been almost as little planning to the end that the working life should be made more or less degrading or richer or poorer in human interest. For although the technicians have often pointed proudly to the elimination of rough and irksome labor, they have been able to claim it only as an "incidental" and sometimes as an "unsuspected" benefit; their main concern has been of necessity with other considerations. And so even more clearly for the other side of the picture; for whatever a strayed craftsman from Mars might suspect, we can be sure that no race of devils has been devising dull jobs for sheer delight in their dullness.

\section{WILL the Workers Benefit?}

The fact is rather that the busy leaders of the older revolution have driven ahead toward their goals of production and profits with little thought of any of the social consequences and almost no thought of the effect on the quality of the working life. And so through the whole history of technical progress. Certain of the revolutionists of Giant Power, on the other hand, have conceived the far more revolutionary idea that a technical change can be guided and controlled not merely in terms of the need for more goods but rather in terms of social needs in general. They are asking, as this volume indicates, the very new question of how the innovations "can be made to contribute to the fulness of life." But a man's work is still a significant part of his life-and one that we have seen changing sharply with new technique; and those who believe that the differences between one job and another are important determiners of the quality of human living, are justified in asking that these more thoughtful revolutionists consider as part of their problem the question of how the new power will affect the fulness of life on the job. Will the types of 
work under the new order offer to the ordinary man greater or lesser opportunities for dignity and ingenuity and self-expression? Will they bring to the workers more interesting jobs than they are now performing, or will they bring still duller ones?

These questions come with the greater urgency, moreover, because of some of the effects of past increases in industrial power and because of some of the claims that are made by the advocates of this one. Very often it has been just the fact of the cheapening of power that has made possible the substitution of repetitive for skilled and varied work; and certain power enthusiasts are boasting, though perhaps prematurely, that the complete elimination of the "unfortunate human element" from as good a craft as that of the locomotive engineers will be one of the first triumphs of the new revolution. The road of Giant Power is apparently the road of the more complete subordination of the individual to the machine's routine.

The Menace to Personal Freedom

But will not this very loss of individual freedom bring its own corrective? Will it not make the workers more determined and more successful in winning a different sort of freedom through the extension of their union organizations? And may not the opportunities for groups of workers to take a more responsible part in the running of industry make up, and more than make up, for the loss of interest in their special tasks? Very likely this is the more practical direction in which to look for the maintenance of the workers' dignity, and certainly such collective freedom becomes of greater importance to the student of the working life as the chances for self-expression on the job grow less and less.

But here again the past record sug- gests a much more ominous conclusion. Unionism tends to flourish, not where power and mechanization are the greatest, but where they are the least. It is the most thoroughly mechanized workers that are the least likely to be organized; and with hardly an important exception, the strongholds of the labor movement are to be found where the consumption of large-plant power is the least-in the hand trades, in the coal mines and on the railroads, and in certain factory industries that use considerably less than the average 3.2 horsepower per worker. And if the coming of Giant Power is to lead, as many believe, to a scattering of workers in smaller factories and in small towns, the change may add at least as much to the difficulty of union organization as it takes away from the need for it. So far, then, the indications seem to be that the great increase in power-whatever its advantages in other fields - will strengthen the tendencies that run counter to the chances either of individual or of collective freedom in industry.

It is of course possible that these tendencies may be checked. Perhaps some of the newer school of industrial engineers, in their search for a 100 per cent job to standardize, may find that the element of inherent interest is necessary even on grounds of efficiency. Possibly indeed the experiments of the author of Non-Financial Incentivesexperiments made, by the way, in an industry that already uses more than 16 horsepower to the man-may mark the beginning of a return of work that will capture the imagination of the worker. And on the other side it is possible that the unions may meet the difficult problems of the change with new energy and new vision. The late President of the Federation of Labor had at least warned his followers not to let the "tremendous development" of Giant Power "roll its great weight" 
upon an unprepared movement. The startling successes of the clothing workers, moreover, have cast a doubt upon the whole concept of "unorganizable" industries, and Mr. Gompers himself was facing the coming of the giant with at least the outline of a program for active union participation in the running of the power system itself. But in spite of all this, there is little evidence that the labor movement has either the strength or the definiteness of intention that would be necessary for a campaign that might bring a group freedom to the great mass of the workers in the power-using industries, and there is little doubt that the methods of Ford are conquering industry much more rapidly than the methods of Wolf.

\section{The Challenge to Giant Power}

Without guidance, then, Giant Power appears to offer its great promises to society at the cost of a further narrowing of the range of freedom and interest in the working life. Here is a real challenge to the statesmanship of the new revolutionists. Can they give this consideration its proper weight along with the others as they plan the control of the change? Can they devise ways of bringing the benefits of cheap power without chaining the mass of the workers to repetitive machineminding? Or can they so shrewdly strengthen the forces already working for freedom in industry that the dignity of the working life may be maintained whatever the nature of the jobs themselves? Perhaps these things are impossible. It may be that the new development cannot go on without the rigorous subordination of the individual during working hours, and it may well be that the promise of greater leisure and of a richer and fuller life outside the factory is sufficient to outweigh the loss in the quality of the life on the job. But those who "love liberty even in industry" may at least ask the revolutionists not to take this lessening in freedom too easily for granted. If they cannot avert it, let them count it as a real cost-to be recognized even in the chorus of praise for the blessings of the change- and let them at the very least make sure that those who are to bear this cost, and those who are to do these duller jobs, are to be among those who share most richly in the benefits of the new leisure. 